\title{
Ideas and Political Language of PKS Muda Cadres on Social Media
}

\author{
${ }^{1}$ FAJAR NUGRAHA, ${ }^{2}$ ATIE RACHMIATIE, ${ }^{3}$ IRFAN SAFRUDIN \\ ${ }^{123}$ Pascasarjana Universitas Islam Bandung, Jalan Purnawarman No.59, Indonesia, \\ Correspondence author: fajar.nugraha2088@gmail.com
}

\begin{abstract}
PKS (Partai Keadilan Sejahtera/Prosperous Justice Party) Muda as a political party wing based on millennial generation expresses its political ideas and language on distinctive social media, which is interesting to research. Social media has become a space for every individual to create and spread ideas that form his/her political attitudes. This study aims to determine the ideas and political language of PKS Muda cadres regarding the 2019 general election on social media Twitter and Facebook. This study uses a qualitative method, a virtual ethnographic approach and a constructivist paradigm with the research subjects of PKS Muda cadres. The results show that in cognitive orientation, political ideas of PKS Muda cadres conveyed on social media meant to flatter and defend supported parties/candidates, to encourage their viewers to vote, and to criticize political opponents and election organizers. In affective orientation, PKS Muda displays the form of emotions by giving likes to the content they receive or using emoticon symbols to show dissatisfaction with the incumbent's performance. In evaluative orientation, PKS Muda cadres voice their beliefs and feelings by creating and sharing content on social media. Regarding political language, many PKS Muda cadres use net lingo language and often write and share texts on social media in the form of descriptions, narratives, and persuasion, rarely using argumentation and exposition.
\end{abstract}

Keywords: ideas and political language, virtual ethnography, PKS Muda,

\section{Introduction}

Partai Keadilan Sejahtera (PKS) is one of the parties concerned in targeting the millennial segment to become voters, cadres, and even legislative candidates in the 2019 Indonesian general election. PKS has a strategy to get millennial voters by assigning millennial generation as campaign subjects. Pipin Sopian -one of PKS millennial cadre- as the Chair of DPP (Central Leadership Council) PKS for Political Affairs explained that PKS recruited millennials to become legislative candidates for the 2019 Legislative Election with a composition of 30 percent.

PKS formed a party wing of PKS Muda as a place for party regeneration. PKS Muda as part of millennial generation has political activities that cannot be separated from social media. Young political actors (millennial) do have great potential for political power because of their large numbers. The millennial generation was born between 1977 and1994 after generation $X$. This generation lives in an era of information that openly and freely obtained from the internet (Sari, 2018:154).

The involvement of millennial generation in politics is very different from the previous generation. Milkman in the journal American Sociological Review said that millennial generation not only chose Obama, but they actively campaigned for him using social media. In fact, about 2,000 people participated in the "Camp Obama" training, most of whom were in their twenties (Milkman, 2017:8).

The participation of millennial generation cannot be separated from social media. Several studies have found the influence of social media on political knowledge. Social media provides an opportunity for the public to obtain sufficient political content. People choose to switch from physical news media to social media because they can get abundant

Received: 2020-07-23, Revised: 2020-10-07, Accepted: 2020-12-28

Print ISSN: 0215-8175; Online ISSN: 2303-2499. DOI: https://doi.org/10.29313/mimbar.v36i2.6443

Accredited Sinta 2 based on the decree No.10/E/KPT/2019 until 2024. Indexed by DOAJ, Sinta, Garuda, Crossreff, Dimensions 
news content, not only from mainstream news portals but also from various alternative news providers such as citizen journalists, civil organizations, non-profit organizations, and individuals as citizens (Park, 2019).

Another study shows that social media has equality in political participation of young people. Young people convey their political views through social media by creating their own political content and contributing to making narratives in mainstream media, and this causes the interest and political participation of young people to increase (Sener, 2019).

Social media has changed political communication dramatically by incorporating the logic of new media into communication. The logic of new media is based on interactions with many people where information is interconnected, while traditional media logic is based on too much communication and is subject to journalistic ethics (Guðmundsson, Kristjánsdóttir, \& Hjálmarsdóttir, 2019). Social media has changed the level of participation of voters and the public. Since people use social media with high intensity, then social media can influence participation in political process (Saud, 2020:84). This makes social media have a socio-political life with a new public space in the life of a virtual community. Virtual community life is a community life that cannot be directly sensed through human senses but can be felt and witnessed as a reality (Bungin, 2017:37).

Blumer and Kavanagh (Blumler, 2001) are aware of the emergence of a "third age of political communication" in which print and broadcast media are no longer the main channels of political communication in a new era filled with abundant information. When Blumer and Kavanagh wrote that "political ideas, information and news can be disseminated via computers", they thought of the "internet web" and communication technology with the capacity to achieve a twoway flow of information that allows users to search for certain types of news (Heryanto, 2018:24)

The existence of social media also has a strong influence on social change in society. McLuhan in (Rosyidah \& Nurwati, 2019:14) revealed that in this era, people have been connected through internet communication technology with social media as part of it.

Ganley in (Wahid, 2016:80) states that social media allows individuals to play a more active role as citizens as well as consumers since it increases access from ordinary citizens to be more politically informed which in turn enhances democracy. This phenomenon is known as citizen journalism.

In authoritarian countries such as Egypt and Libya, the function of communication is often facilitated by social media as it provides a virtual space for information and various opinions and builds communities that can mobilize collective action. Thus, the communication function in social media can encourage political participation and form a democratic society (Chen \& Chan, 2017:1).

Currently, social media is one of the main channels for generating political ideas, especially among millennial generation. Social media provides a space for each individual to participate in consuming and producing and distributing ideas. Through social media, the political attitude of millennial generation can be formed (Atmodjo, 2014).

Figure 1 is state of the art of this research.

This study aims to examine the ideas and political language of the 2019 general

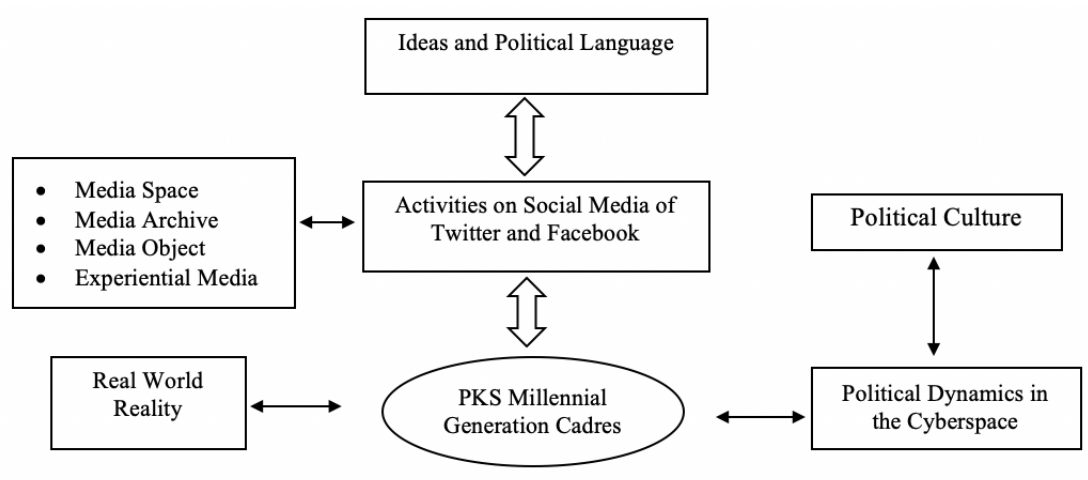

Figure 1. State of The Art 
election on social media Twitter and Facebook among PKS millennial generation cadres. PKS millennial generation becomes the subject of this research due to the reason that PKS is one of the parties that focuses on regenerating the millennial generation, including making them the subject of the campaign as legislative candidates at all levels of legislature. Therefore, political communication activities on social media carried out by PKS Muda cadres become the attention of researchers in seeing political ideas and language among the millennial generation.

Text (language) on social media is cyber social reality that produces what is called culture. Interactions between users and applications that involve the structure of users on social media in a certain time and location will produce culture. This culture is cyberculture where cyber social reality only occurs in virtual world. Therefore, text or content becomes cultural artifacts (Nasrullah, 2014: 35). Netlingo is writing on social media as if it speaks. Text written on social media becomes language (text) which represents expressions when speaking. Therefore, every word or sentence written on social media is as if it were a speech or sound and its intonation in daily conversations (Ayun, 2016:116)

The researchers noted that for the Bandung City DPRD (Regional Representative Council) level, PKS millennial cadres who became legislative candidates were $12 \%$ or 5 out of 43. For the DPR RI (The People's Representative Council of the Republic of Indonesia) level, from all voter areas in West Java, there were $8 \%$ or 6 of the 79 of PKS candidates. The average age of these millennial candidates was 25 to 35 years. This proved to the public that PKS was truly a party that focused on and has succeeded in conducting coaching among young people from the regional to national levels.

In the column of PKS millennial generation cadre, researchers draw lines to the right and left that contain realworld realities and virtual world realities. Researchers will explore the relationship between political ideas that exist in the real world and cyberspace. Users on social media are not new audiences who do not have identities and they have obtained values that exist in society. Researchers discover that the activities of the millennial generation on social media are closely related to the realities occur in the real world.
Ideas built on social media are not only seen from the micro-unit, but also from the macro unit. The level of media experience is imperative for researchers to see the motives of the ideas made by the informants. This idea is reflected in a text produced by the informant. Researchers are looking for what underlies users in constructing a text that is shared via social media.

Concerning political communication, the political ideas created by PKS millennial generation cadres and distributed on social media of Twitter and Facebook are part of political communication. Doris Graber (1981) said that political communication does not only rhetoric, but also includes language symbols such as body language and political actions such as protests and demonstration (Slamet \& Aprilliani, 2018:77).

To view ideas on social media, the researchers use virtual ethnographic approach to provide an overview of activities on social media. In examining political ideas on social media of Twitter and Facebook, researchers looked at the context of media space, media archive, media objects and experiential media. It turns out that media space can reveal the structure of instruments and the appearance of political ideas in the media that are linked to procedures or applications of a technical nature. Media archive views the process of political communication from the content and meaning of the text/graphics as artifacts of political culture. Media objects see the political communication process from the context of interactions occur on social media, as well as the communication between social media users. Whereas in the context of experiential media, researchers will observe the communication process by motives, effects, benefits or realities that are connected offline or online.

\section{Research Methodology}

This research uses a qualitative method, in which the researcher will examine the meanings of political ideas contained in social media conversations. As stated by Dedi Mulyana, qualitative research is used to examine things within the phenomena based on the meanings people give to these things. Qualitative methodology tends to be associated with the desire of researchers to examine the meaning, context, and a holistic approach to phenomena (Mulyana, 2018). This study uses a virtual ethnographic approach to 
reveal the reality, both visible and invisible, of computer-mediated communication among virtual community entities on the internet. As stated by Christine Hine in (Achmad \& Ida, 2018) virtual ethnography is a methodology used to investigate the internet and explore entities (users) when using the internet. Virtual ethnography also reflects the implications of internet-mediated communication (Nasrullah, 2017).

The paradigm used in this research is constructivist paradigm, which is subjective. Research conclusions come from the observations and experiences of researchers in interacting with data and observations. Referring to Richard West's (2017) view of the constructivist paradigm, the interpretive approach is subjective truth and was co-created by the participants and the researchers involved in it. However, this does not mean that research in this approach should rely entirely on what participants say without judgment from the outside. For researchers, this interpretive approach is accompanied by the best theory that is induced from observations and experiences of researchers and audiences as informants (West, 2017).

In determining the research subject, the researchers used purposive sample, namely the determination of sample in accordance with the research objectives. The purpose of sampling is to get as much information as possible from various sources and constructions (Moleong, 2017). To determine informants, researchers identify the types of users or members of virtual community itself. Kozinets (2002) in (Nasrullah, 2017), defines the types of social media users as tourists, minglers, devotees, and insiders. Tourists are the type of user who is not active on social media. Minglers are an active user on social media, but does not show much interest in political information. Devotes are those active on social media, but make little contact and interacts with other users. Finally, insiders are active social media users who interact with each other in consuming and producing information content. Hence, PKS Muda cadres who have the type of devotees and insiders are chosen as important sources to answer problems in virtual ethnographic research.

Primary data in this study were obtained from observations in cyberspace as a unit of analysis for virtual ethnographic research. Observations were conducted to social media used by informants as a means of consuming and producing information related to politics. Apart from observations, primary data were also obtained from face-to-face interviews with sources. Interviews are intended to reveal the reality behind the language of the text created and uploaded on social media. Secondary data were obtained from documents in the form of books and journals related to this research.

Based on the results of observations and interviews, the researchers conducted an analysis using the Cyber Media Analysis (AMS) technique. This technique serves as a guide to elaborate on the realities, both online and offline, as well as how cyber media technology devices are used or influence the formation of ideas and political language among millennial generation.

There are four units' levels in Cyber Media Analysis, namely media space, media archive, media object and experiential media (figure 2). Media space and media documents levels focus more on cyberspace in micro-unit or text, while media objects and experiential media are multilevel analyses that see how real reality (offline - through interviews) has a relationship with reality online. Media objects and experiential media reside in a micro-unit or context. Each level has a connection and what appears in context comes from the text and the text is processed first through technological procedures in cyber media (Nasrullah, 2018:281)

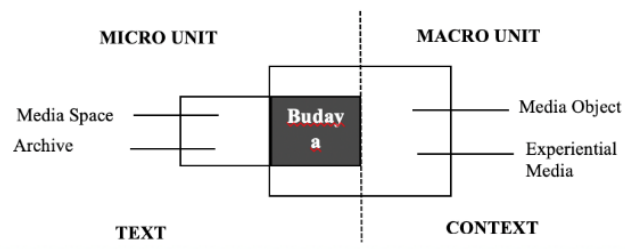

Figure 2. Cyber Media Analysis

Source: Nasrullah, 2017:44

\section{Results and Discussion}

\section{Political Ideas of PKS Muda Cadres}

The researchers found that political ideas in political messages conveyed by PKS millennial generation cadres through social media of Twitter and Facebook are: first, ideas to flatter the supported party or candidate, which is the conveyance of the superiority of supported party or candidate. Second, ideas to defend supported party/candidate, which is the clarification of negative attacks/ black campaign by political opponents. These 
tweets appeared as responses to the tweets of other people who criticize or demonize Prabowo-Sandi pair (a presidential candidate pair supported by PKS). Third, ideas to encourage audiences to vote, which is a direct persuasion to vote for the party or

candidate supported by PKS. Fourth, ideas to criticize/attack political opponents, which is negative campaigns against political opponents. Fifth, the idea to criticize the election organizers, which is concerning fraud done by the election organizers.

Table 1 is sample of conversation containing the five elements of ideas above.

Viewing the political messages produced and distributed by PKS millinneal generation cadres, researchers find the political idea in the context of encouraging people to vote for supported parties or candidates is more dominant than others, namely $36 \%$; but criticism or attack on political opponents are also quite high, namely $33 \% ; 12 \%$ convey the superiority of supported party or candidate; $7 \%$ criticize election organizers, and $6 \%$ defend against criticism or attacks from political opponents. This can be seen in graph 1.

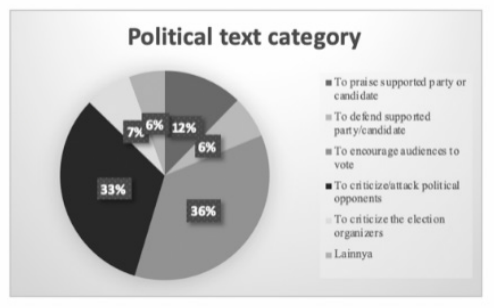

Graph 1. Political Text Category

Source: Processed by Researchers, 2020

In political culture, "ideas" are part of political cognition (mindset) of political

Table 1

The Meaning of PKS Muda Cadres Conversation

\begin{tabular}{|c|c|c|c|}
\hline Type of Ideas & Informant & Conversation & Meaning of Conversation \\
\hline $\begin{array}{l}\text { To praise } \\
\text { supported party } \\
\text { or candidate }\end{array}$ & $\begin{array}{l}\text { @Siti Wulansari } \\
\text { Basidi }\end{array}$ & 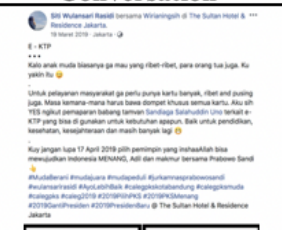 & $\begin{array}{l}\text { E-KTP is one of the hallmarks } \\
\text { of the Prabewe-Sandi campaign }\end{array}$ \\
\hline $\begin{array}{l}\text { To defend } \\
\text { supported } \\
\text { party/candidates }\end{array}$ & @andiiaxakusumah & 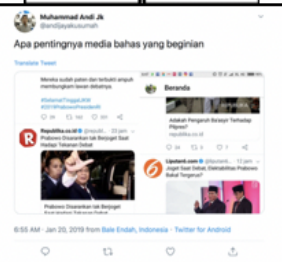 & $\begin{array}{l}\text { Defending Prabowe who was } \\
\text { reported dancing during the } \\
\text { presidential debate }\end{array}$ \\
\hline $\begin{array}{l}\text { To encourage } \\
\text { audiences to } \\
\text { vote }\end{array}$ & @awahuudin & O- & $\begin{array}{l}\text { Encouraging people to vote } 02 \\
\text { creatively }\end{array}$ \\
\hline $\begin{array}{l}\text { To } \\
\text { criticize/attack } \\
\text { political } \\
\text { opponents }\end{array}$ & (a)sundanesia_02 & 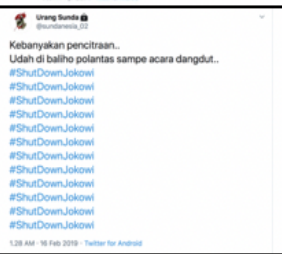 & $\begin{array}{l}\text { Attacking political opponents by } \\
\text { getting \#ShutDownJokowi to } \\
\text { become trending }\end{array}$ \\
\hline $\begin{array}{l}\text { To criticize the } \\
\text { election } \\
\text { organizers }\end{array}$ & (a) nxpnхрихn & (5) & $\begin{array}{l}\text { Questioning the KPU's policy of } \\
\text { using ballot boxes made of } \\
\text { cardboard }\end{array}$ \\
\hline
\end{tabular}

Source: Processed by Researchers, 2020 
groups that reflect the platform, vision and power goals the party wants to achieve. Social media as a new media tool is also part of the emergence of the culture. The idea shared by PKS millennial generation cadres on social media is a form of political culture as ideas, values, and patterns of human action are conveyed through social media devices.

The idea of encouraging people to vote conveyed by PKS millennial generation cadres on social media contains positive and creative themes. The campaign is more intended to get sympathy from other millennial generations. Criticism/attacks on political opponents mostly use the language of satire to the perceived reality in the real world.

Social media among PKS millennial generation cadres is not only used for self-disclosure or self-existence alone, but it has increased to become a medium for online citizen aspirations. For example, the submission of criticism of the government uploaded by the @ sundanesia_02 account as shown in figure 3 .

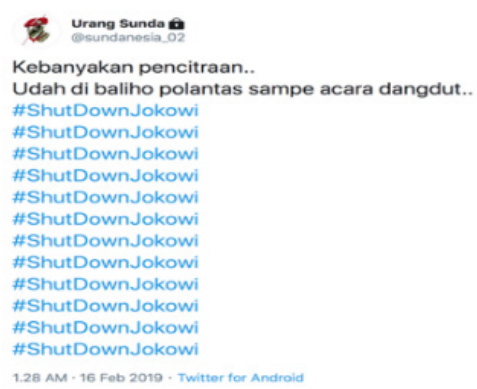

Figure 3. Example of Tweet about Criticism/ attacks on Political Opponents

Source: Twitter Timeline of @sundanesia_02 on February 16, 2019

Erip, the owner of @ sundanesia_02 account, believed that the incumbent used state facilities to promote himself. Criticism is also conveyed to election organizers uploaded by Nur Yunita as the owner of @nypnypnyp account who tweeted that the ballot box in Mampang district was eaten by termites:

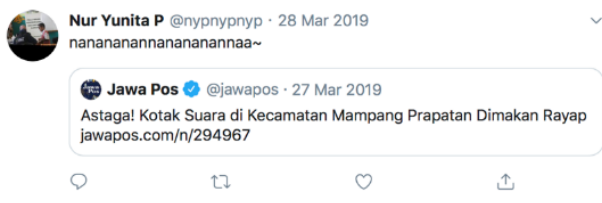

Figure 4. Example of Tweet about Criticism to Election Organizer

Source: Twitter Timeline of @nypnypnyp on March 28, 2019
Nur Yunita expressed her disapproval of the KPU's policy of using cardboard ballot box which was considered to have a risk of fraud (figure 4). This shows how social media is used by millennials to voice their thoughts and opinions in the democratization process.

The formation of political ideas on social media cannot be separated from the four levels of Cyber Media Analysis unit. In the context of political ideas, researchers view from the aspect of media space as a microunit; media object, and experiential media as a macro unit or context.

The level of media space reveals the structure and tools of social media. For example, the social media structure of Twitter and Facebook has a wall facility as a place for users to convey ideas, publish opinions, or inform a political reality. Other facilities exist in social media structure of Twitter and Facebook are share or retweet/replay. Through this facility, users not only create and consume content but also distribute and develop it (Nasrullah, 2018a). @ tweenarra2 account often use this facility by the reason that he/she lacks knowledge about politics and prefers to retweet (figure 5).

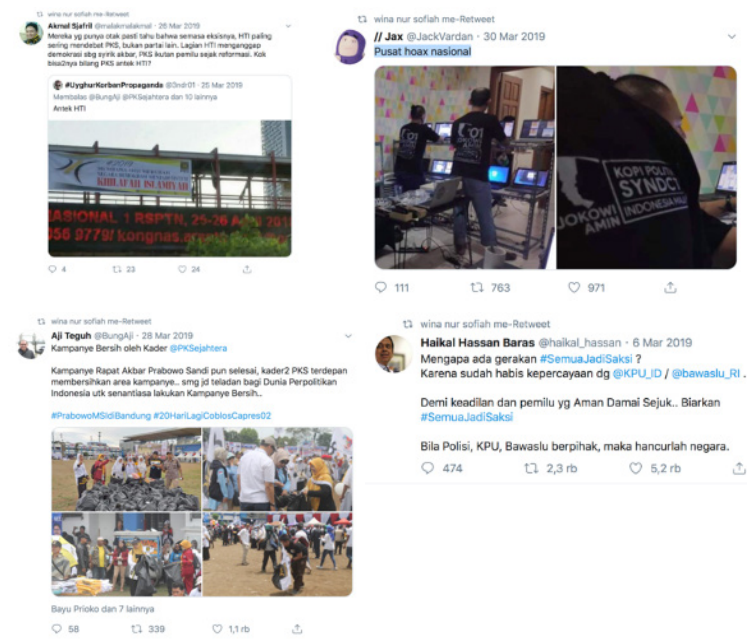

Figure 5. Example of Retweet about Political Ideas

Source: Twitter Timeline of @tweenarra2

There are several reasons why share or retweet is important for users: first, it is an effort to share important information to other members of the social media community; second, it shows the position or partisanship of the audience on an issue or information disseminated; third, disseminated content is a means of adding new information or data that will complete the content (Nasrullah, 2018a). Share or retweet activities carried 
out by users show the position of taking sides with ideas produced by others.

Theoretically, there are 3 (three) levels of a person's orientation in culture and political behavior, namely cognitive, affective and evaluative aspects. Cognitive orientation concerns knowledge and belief in the political system, affective orientation concerns feelings about the political system, and evaluative orientation concerns decisions and opinions about political objects (Almond, 1984).

At the cognitive level, informants display diverse content ranging from problems occur, building the image of supported candidate or party, defending the supported candidate or party, encouraging people to vote, exposing weaknesses/negative side or shortcomings of other candidate pairs, and criticizing election organizer. Some informants considered that social media content was produced as part of driving public opinion.

At the affective level, informants express their feelings by tweeting annoyance towards the incumbent's performance and indication of fraud committed by the KPU, giving like on the content they receive, and retweeting or sharing as a form of expressing feelings towards content on social media. At the evaluative level, informants voice their beliefs and feelings by producing and distributing content on social media.

The orientation of political ideas of PKS Muda cadres is not only at the cognitive and affective level, but also get into evaluative orientation. This orientation is a mixture of cognitive and affective orientations in forming a decision (Rachmiatie, Hasbiansyah, Khotimah, \& Ahmadi, 2017:125). Defending the presidential candidates and the parties they have chosen is the result of their knowledge and belief. This evaluative orientation arises as a result of the influence of cognitive and affective orientations.

The ideas that emerged through Twitter and Facebook of PKS millennial generation cadres were the result of interaction and communication between users, which continuously created a reality that was shared and experienced subjectively.

PKS cadres believe that politics cannot be separated from Islam; Islamic values are always present in every political idea that appears on social media of Twitter and Facebook. Abu Ridha, one of the founders of PKS, said that politics is inseparable from Islam because Islam covers and regulates all life systems, including politics (Abu Ridha, 2018)

In socio-cyber reality, appearance on social media is the result of reconstruction or construction of interaction and communication between users. Figure 6 is a model modified by the researchers related to Facebook and Twitter account tweets about political ideas regarding the 2019 general election among PKS millennial generation cadres.

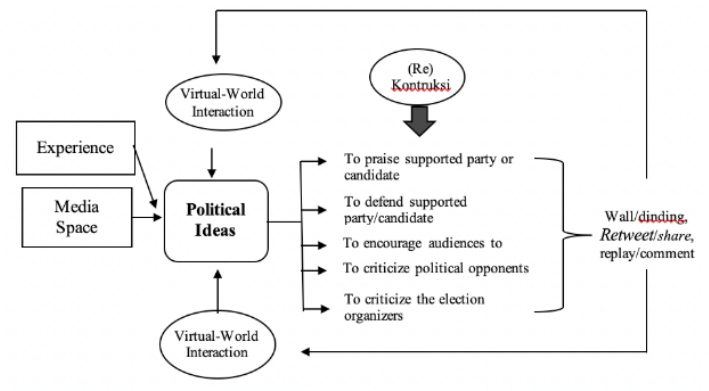

Figure 6. Model of Political Ideas Regarding the 2019 Elections

Source: Processed by Researchers, 2020

\section{Political Language of PKS Muda Cad- res}

Political language according to Beard in (Harthaty, 2020) is the language used for political purposes or the language used in communication for the benefit of regulating other people or communities. Political language is often used by political and bureaucratic elites to convey the interests of power. In the digital era, political language is often used by the general public outside the political elite. However, the language used by political elite was packaged into a different style.

The reality of social media can be seen at the level of media documents, which are used to view content as text and the meaning contained in it is duplicated through social media. The text developed by PKS millennial generation cadres becomes the highlight for the researchers to be interpreted as a socialcyber reality. Text produced by informants on social media does not merely represent the ideas or opinions of social media users. Text can show ideology, political views, to cultural forms (Nasrullah, 2018b:29).

There are two terms commonly applied to view the language used on social media, namely netspeak and netlingo. Researchers saw that the activities of PKS millennial generation cadres on social media mostly used netlingo language as shown by tweets 
of @nypnypnyp account (in figure 7).

Nur Yunita P @nypnypnyp·30 Mar 2019

Membalas @nururusti

to ga sadar dia teh serakah . nyri2 ksalahan org lain seolah2 dia itu bener

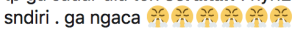

Q

个

Figure 7. Example of Tweet Using Netlingo

Source: Twitter Timeline of @nypnypnyp on March 30, 2019

To examine the meaning contained in the tweet language of informants' personal Twitter and Facebook accounts, the researcher used Peirce's triangle of meaning theory consisting of sign, object, and interpretant. Sign is a major concept that can represent an object. Object is a social context that is a reference to a sign or something that is referred to as a sign. Interpretant is a sign in a person's mind about the object that is referred to by a sign (Sobur, 2018).

Referring to Peirce's theory, signs in social media can be seen from icons and symbols. A sign is something that represents something, namely experiences, thoughts, ideas or feelings (Suryandari, Dyah Kurniasari, \& Dian J, 2019).

Researchers found five forms of tweets on social media Twitter and Facebook produced and distributed by millinneal generation of PKS cadres. The first one, sign can be found in the words "April 17, 2019, people power, pilih PKS (vote for PKS), rekam jejak PKS (PKS track record), and coblos caleg PKS (voting for PKS candidates)". The object of sign is pilih Prabowo dan PKS (vote for prabowo and PKS). Interpretant in the sign that refers to object is an encouragement to vote. Second, the sign is in the words "pengangguran di gaji (unemployed get paid), diiming-imingi (being lured), $8 \mathrm{M}$ untuk serangan fajar ( 8 $M$ for dawn attacks), pencitraan (imaging), and capres bohong (lying candidates)". The object of sign is the negative side of JokowiMa'ruf candidates; interpretant is to criticize or attack political opponents.

Third, the sign is in the word "debat tanpa teks (debate without text), e-KTP digunakan kebutuhan apapun (e-KTP is used for any need), and ada agama lain (there are other religions)". The object of sign is the positive side of presidential candidate Prabowo-Sandi. The interpretant is to flatter the supported party's candidate. Fourth, the sign is in the words "kemana arah KPU berpihak (where does the KPU take sides), kecurangan masif (massive fraud), KPU jangan curang (KPU should not cheat), and kotak kardus (cardboard boxes)". The object of sign is the injustice committed by the KPU. The interpretant is to criticize the election organizers. Fifth, the sign is in the words "ga penting bahas beginian (it's not important to discuss this), ga selevel (not at the same level), lucunya wartawan now, seolah-olah bener sendiri (how funny the reporters now, as if they are genuinely true)". The object of sign is defending Prabowo and PKS; while the interpretant is to defend the supported party or candidate.

There are three forms of language frequently and mostly used by PKS millennial generation cadres in producing and distributing political messages on social media, namely description, narration, and persuasion; while the form of argumentation and exposition are rarely being used.

The text typed by @andijayakusumah account contains a description form as shown in figure 8.

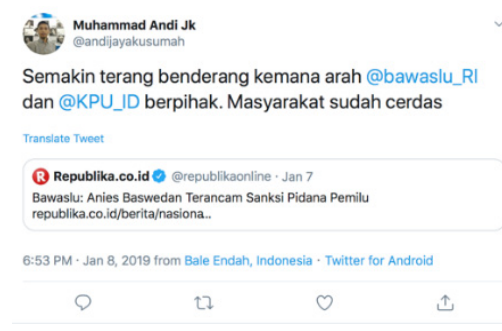

Figure 8. Example of Descriptive Tweet

Source: Twitter Timeline of @andijayakusumah on January 8, 2019

The form of this message is included in a description that only provides an overview to the public on where the Bawaslu and KPU take side.

Descriptive discourse is used to generate impressions about a person, place, etc. (Arini, 2013). @andijayakusumah typed the text to give a certain impression to the election organizers. Other impressions to convey are the impression of enthusiasm and the number of 02 supporters, the impression of young people who choose PKS, the impression of Jokowi's program and performance, the impression of media and political parties.

The form of narrative discourse text is also widely used among PKS millennial generation cadres on social media. Narrative form is a text that tries to describe as clearly 
as possible to the reader an event that has occurred (Arini, 2013). We can see it in figure 9 Facebook account of Sejuta Arif.

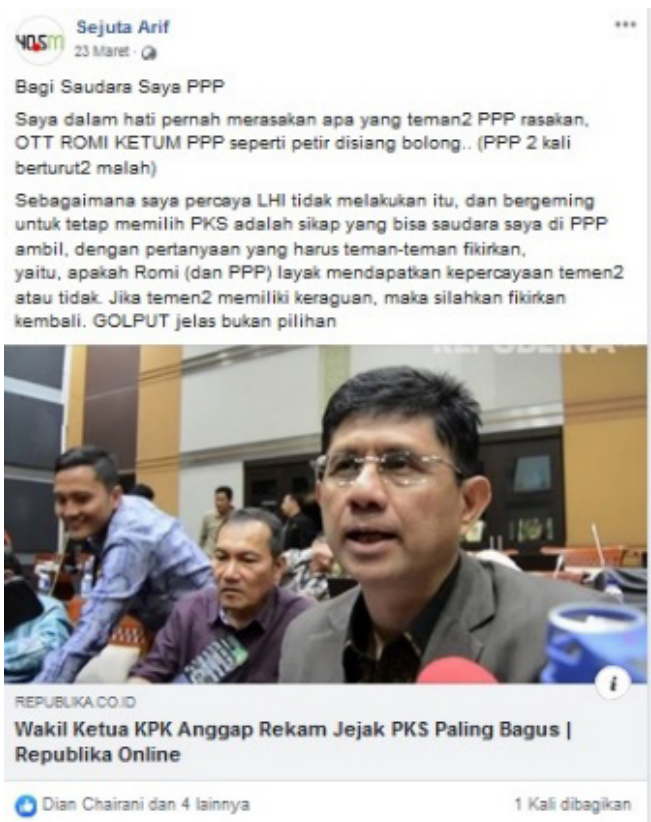

Figure 9. Example of Narrative Tweet

Source: Facebook Timeline of Sejuta Arif Account on March 23, 2019

In the text above, Arif explains the story of a sting operation or OTT (Operasi Tangkap Tangan) of the general chairman of PPP (Partai Persatuan Pembangunan or United Development Party) and the experience of PKS president who got caught in OTT as well. In his message, Arif wanted to convey to the public that "abstaining or golput" is not an option. There are still parties with the least number of cadres who stumble over corruption.

Other stories conveyed by informants on their social media accounts related to the attitudes of Jokowi supporters, corruption from parties supporting the 01 presidential candidates, superiority of the 02 campaign, the PKS president, and the story of election organizers.

In addition to descriptive and narrative text forms, there is persuasion text used by PKS millennial generation cadres in producing texts on social media. This form of persuasion implies persuasion or suggestion. Persuasion first presents ideas with reasons, evidence, or examples to convince the audience, then followed by invitations, persuasions, enticements, recommendations or suggestions. An example of persuasion text can be seen in the following tweet of @nypnyp Twitter account in figure 10.
Nur Yunita P @nypnypnyp - 8 Apr 2019

disana yg hadir maupun yg tidak hadir (termasuk saya) , yg ddlmny tdk hanya umat Muslim tp juga ada agama lain samasama berharap Indonesia bisa dipegang oleh pemimpin yg amanah. samasama berharap Allah, Tuhan Yang Maha Esa, senantiasa melindungi negara Indonesia dr hal2 apapun

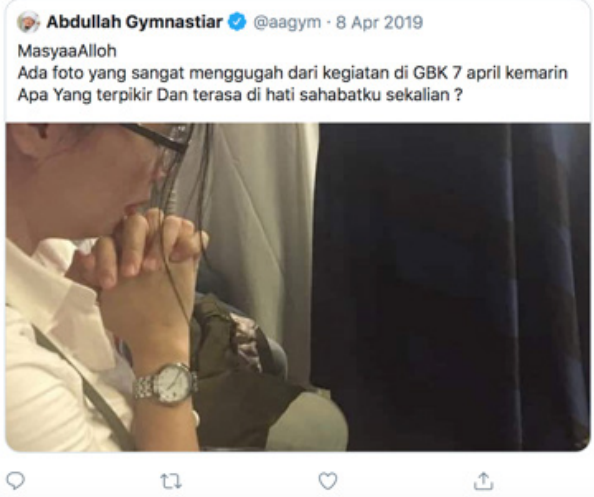

Figure 10. Example of Persuasive Tweet

Source: Twitter Timeline of @nypnypnyp on April 8, 2019

The text above describes the idea that all religions support 02 candidates; the evidence is presented through a photo of a non-Muslim praying in the Prabowo-Sandi grand campaign. It was then followed by an implicit invitation sentence hoping that the leader to come is a trustworthy one.

To view the political language of PKS Muda cadres, researchers made a political language model regarding the 2019 general election on social media of Twitter and Facebook among PKS millennial generation cadres as in figure 11.

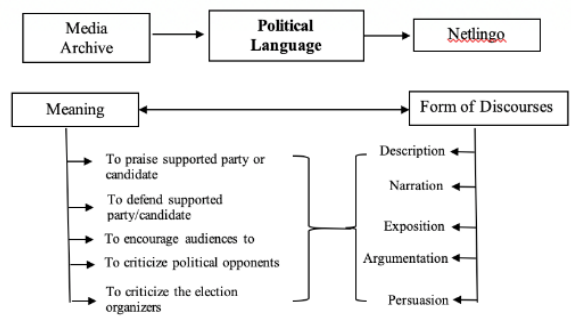

Figure 11. Model of Political Language in 2019 Election

Source: Processed by Researchers, 2020

Referring to Peirce's theory, sign in social media can be seen from icons and symbols. Text is part of the symbols produced by PKS millennial cadres on social media. Researchers found five meanings of tweets contained in symbols or signs produced on social media by PKS millennial cadres. This meaning consists of encouraging people to vote, criticizing or attacking political opponents, flattering the supported candidate's party, criticizing 
election organizers, and defending the supported party or candidate.

Based on the five meanings above, PKS millennial cadres are included in the type of participant culture classified by Almond (1984), namely a political culture in which PKS millennial cadres already have an explicitly political orientation towards political structures and processes. PKS millennial cadres have an awareness of their political rights (Saleh \& Munif, 2015:316).

\section{Conclusions}

The ideas and political language of PKS Muda cadres on social media are a manifestation of political culture conveyed through social media. On a cognitive orientation, the political ideas conveyed by PKS millennial cadres contain the meaning of flattering supported parties/candidates, defending supported parties/candidates, encouraging people to vote, criticizing/ attacking political opponents, and criticizing election organizers. In affective orientation, the feelings are shown on social media through emoticon symbols or give likes to the content received or the expression of dissatisfaction with the incumbent's performance. In evaluative orientation, informants voice their beliefs and feelings by producing and distributing content on social media.

PKS millennial generation not only uses social media for self-existence but also a medium for online citizen aspirations. The political ideas produced and distributed by PKS millennial generation cadres are realities in the real world and cyberspace. Submission of a text containing the context of an idea is channeled through the wall, retweet or share and replay or comment. This activity is a political communication that does not only speak rhetoric but also includes language symbols, as well as political actions in the social media space.

The reality experienced by PKS millennial cadres online on social media is connected to offline activities. This reality is the result of the reconstruction or construction of interaction between users as a social-cyber reality on social media.

PKS believes that politics cannot be separated from Islam. This belief emerged as a result of cadres' internalizing process of Islamic values offline so that their beliefs were reflected in tweets on social media that carried Islamic values.
In the use of political language, most PKS millennial cadres choose Netlingo. The written language is just like speaking everyday conversations. The forms of language used by PKS millennial generation cadres in conveying political messages vary. There are three forms of language frequently and mostly used by informants in producing and distributing text on social media, namely description, narrative, and persuasion; while argumentation and exposition are rarely being used.

Based on the results of the research, it is hoped that political ideas on social media should become positive political education for millennials and can avoid black campaigns or negative political ideas. Millennials as party cadres are expected to be able to emulate noble values in the party platform, apply participant culture, and continue to use political language in the corridor of ethics.

\section{Acknowledgments}

The researchers would like to express their sincere gratitude to the Ministry of Research and Technology \& National Research and Innovation Agency and LPPM UNISBA (Bandung Islamic University) for financing this research through the Master's Thesis Research Grant.

\section{References}

Abu Ridha. (2018). Politik Tegak Lurus PKS (Ali Ghufron, ed.). Solo: Era Adicitra Intermedia.

Achmad, Z. A., \& Ida, R. (2018). Etnografi Virtual Sebagai Teknik Pengumpulan Data Dan Metode Penelitian. The Journal of Society \& Media, 2(2), 130. https://doi. org/10.26740/jsm.v2n2.p130-145

Almond, G. A. (1984). Budaya Politik: Tingkah Laku Politik dan Demokrasi di Lima Negara (1st ed.; S. Simamora, ed.). Jakarta: Bina Aksara.

Arini, A. D. (2013). Bentuk, Makna, dan Fungsi Bahasa Tulis Media Sosial sebagai Alat Komunikasi dan Interaksi pada Internet. Skriptorium, 2(Nomor 1), 35-49. https:// doi.org/10.1002/ejoc.201200111

Atmodjo, T. (2014). Tri Atmodjo: Dinamika Partisipasi Politik melalui Sosial .... 13(02), 281-295. https://doi.org/http://dx.doi. org/10.22441/jvk.v13i2.1659

Ayun, P. Q. (2016). PENGGUNAAN INSTANT MESSANGER dan KOMUNIKASI 
INTERPERSONAL REMAJA. Jurnal Ilmu Sosial, 15(2), 111. https://doi. org/10.14710/jis.15.2.2016.111-120

Blumler, J. (2001). The third age of political communication. Journal of Public Affairs, 1, 201-209. https://doi.org/10.1002/ pa.66

Bungin, B. (2017). Sosiologi Komunikasi (9th ed.). Jakarta: 2017.

Chen, Z., \& Chan, M. (2017). Motivations for Social Media Use and Impact on Political Participation in China: A Cognitive and Communication Mediation Approach. Cyberpsychology, Behavior, and Social Networking, 20(2), 83-90. https://doi. org/10.1089/cyber.2016.0174

Guðmundsson, B., Kristjánsdóttir, V. K., \& Hjálmarsdóttir, H. B. (2019). Politics, Marketing and Social Media in the 2018 Local Elections in Iceland. 15(2), 161-182. https://doi.org/10.20472/ iac. 2019.051.012

Harthaty, I. (2020). Lexical modal in political languages in America. International Journal of Research in Business and Social Science, 9(7), 212-216.

Heryanto, G. G. (2018). Media Komunikasi Politik. Yogyakarta: IRCiSoD.

Milkman, R. (2017). A New Political Generation: Millennials and the Post-2008 Wave of Protest. American Sociological Review, 82(1), 1-31. https://doi. org/10.1177/0003122416681031

Moleong, L. J. (2017). Metodologi Penelitian Kualitatif (36th ed.). Bandung: Remaja Rosdakarya.

Mulyana, D. (2018). Metode Penelitian Kualitatif (9th ed.). Bandung: Remaja Rosdakarya.

Nasrullah, R. (2014). Teori dan Riset Media Siber. Jakarta: Kencana Prenada Media.

Nasrullah, R. (2017). Etnografi Virtual: Riset Komunikasi, Budaya, dan Sosioteknologi di Internet. Bandung: Simbiosa Rekatama Media.

Nasrullah, R. (2018a). Media Sosial. Bandung: Simbiosa Rekatama Media.

Nasrullah, R. (2018b). Riset Khalayak Digital: Perspektif Khalayak Media Dan Realitas Virtual Di Media Sosial Public Digital Research: Media Perspective and Virtual Reality in Social Media. Jurnal Sosioteknologi, Volume 17,
271-287. https://doi.org/http://dx.doi. org/10.5614\%2Fsostek.itbj.2018.17.2

Park, C. S. (2019). Learning Politics From Social Media: Interconnection of Social Media Use for Political News and Political Issue and Process Knowledge. Communication Studies, 70(3), 253-276. https://doi.org /10.1080/10510974.2019.1581627

Rachmiatie, A., Hasbiansyah, O., Khotimah, E., \& Ahmadi, D. (2017). Strategi Komunikasi Politik dan Budaya Transparansi Partai Politik. MIMBAR, Jurnal Sosial Dan Pembangunan, 29(2), 123. https://doi. org/10.29313/mimbar.v29i2.384

Rosyidah, F. N., \& Nurwati, N. (2019). Gender dan Stereotipe: Konstruksi Realitas dalam Media Sosial Instagram. Share: Social Work Journal, 9(1), 10. https://doi. org/10.24198/share.v9i1.19691

Saleh, K., \& Munif, A. (2015). Membangun Karakter Budaya Politik Dalam Berdemokrasi. Addin, 9(2), 309-332.

Sari, R. L. (2018). Komitmen Organisasi pada Dosen Generasi Milenial. Psikohumaniora: Jurnal Penelitian Psikologi, 3(2), 153. https://doi.org/10.21580/pjpp.v3i2.2791

Saud, M. (2020). The Social Media and Digitalization of Political Participation in Youths: An Indonesian Perspective. Society, 8(1), 83-93. https://doi. org/10.33019/society.v8i1.160

Sener, G. (2019). Youth and Party Politics in Digital Era: Social Media Practices of Young Members of Political Parties in Turkey. Global Media Journal, 10(19), $1-23$.

Slamet, A., \& Aprilliani, D. S. (2018). Ekologi Politik Dalam Komunikasi Politik Menjelang Pemilihan Gubernur Jawa Barat Tahun 2018. Jurnal I/mu Politik Dan Komunikasi, 8(1). https://doi.org/10.34010/jipsi. v8i1.878

Sobur, A. (2018). Analisis Teks Media (8th ed.). Bandung: Remaja Rosdakarya.

Suryandari, N., Dyah Kurniasari, N., \& Dian J, R. (2019). Makna Simbol Tradisi Jheng Manthoh. Jurnal SEMIOTIKA, 13(1), 124-132.

Wahid, U. (2016). Komunikasi Politik Teori, Konseo, dan Aplikasi Pada Era Media Baru. Bandung: Simbiosa Rekatama Media.

West, R. (2017). Pengantar Teori Komunikasi. Jakarta: Salemba Humanika. 